\title{
Efficacy and safety of early comprehensive cardiac rehabilitation following the implantation of cardioverter-defibrillator
}

\author{
Jacek Śmiałek ${ }^{1}$, Jacek Lelakowski ${ }^{2}$, Jacek Majewski ${ }^{2}$ \\ 'Department of Rehabilitation, John Paul II Hospital, Krakow, Poland \\ ${ }^{2}$ Department of Electrocardiology, Jagiellonian University Medical College, John Paul II Hospital, Krakow, Poland
}

\begin{abstract}
Background: Implantable cardioverter-defibrillator (ICD) therapy is current the main approach to prevent sudden cardiac death. It was demonstrated that patients with ICD are characterised by worse quality of life (QOL) and exercise capacity and are prone to depressive symptoms. Thus, comprehensive rehabilitation is indicated in ICD recipients.

Aim: To evaluate safety and benefits of comprehensive cardiac rehabilitation early after ICD implantation.

Methods: The study group consisted of 45 patients (28 males, mean age 62.2 years) in whom a program of comprehensive cardiac rehabilitation was initiated at 6 weeks after ICD implantation. Rehabilitation consisted of two phases: 2-week inpatient Phase I and 12-week outpatient Phase II. Before and after the rehabilitation program, all patients were evaluated with transthoracic echocardiography, treadmill spiroergometric exercise test according to the modified Naughton protocol, a Polish version of the SF-36 questionnaire to assess QOL, and the Beck Depression Inventory (BDI) for depressive symptoms.

Results: No deaths during the study and no complications or adverse events during rehabilitation or exercise testing were noted. Following comprehensive cardiac rehabilitation, we found an increase in left ventricular ejection fraction $(30.09 \pm 12.75$ vs. $35.43 \pm 13.4 \% ; p=0.002)$, peak oxygen uptake $\left(\mathrm{VO}_{2}\right)(21.3 \pm 9.2 \mathrm{vs} .24 .2 \pm 10.3 \mathrm{~mL} / \mathrm{kg} / \mathrm{min} ; \mathrm{p}=0.007)$ and duration of exercise $(9.14 \pm 3.7$ vs. $9.53 \pm 3.8 \mathrm{~min} ; \mathrm{p}<0.05)$. An improvement was also noted in terms of depressive symptoms, as BDI score decreased (14.81 \pm 9.27 vs. $12.83 \pm 10.75 ; p=0.020)$. QOL improved $(p<0.05)$, particularly the physical index $(p=0.02)$, as was the New York Heart Association class $(p<0.001)$. Improvement in peak $\mathrm{VO}_{2}$ was associated with better QOL (SF-total, $r=-0.34$; and physical index, $r=-0.36$ ). We also found a correlation between alleviation of depressive symptoms (BDI score) and improvement of QOL (SF-total, $r=0.52$ ).

Conclusions: An improvement in left ventricular systolic function, exercise capacity and QOL and a reduction of depressive symptoms were observed in patients who took part in a program of early comprehensive cardiac rehabilitation after ICD implantation. No complications or side effects during rehabilitation sessions or exercise tests were observed in the study group. Key words: implanted cardioverter-defibrillator (ICD), rehabilitation
\end{abstract}

Kardiol Pol 2013; 71, 10: 1021-1028

\section{INTRODUCTION}

Prevalence of sudden cardiac death (SCD) has been estimated at 1-2 cases per $1000(0.1-0.2 \%)$ per year [1]. Implantable cardioverter-defibrillator (ICD) therapy is current the main approach to prevent SCD. Decreased quality of life (QOL) was shown in patients with ICD [2], related to fears of ventricular tachycardia (VT) or ventricular fibrillation (VF) recurrence and
ICD activation, and withdrawal from professional, social, and family activities with increased dependence on other people. In addition, patients with ICD limit their physical activity due to fears of increased heart rate and resulting ICD activation [3]. Following ICD implantation, many patients develop depressive symptoms [4]. Due to the above problems, ICD patients may significantly benefit from comprehensive cardiac

\section{Address for correspondence:}

Jacek Majewski, MD, PhD, Department of Electrocardiology, Jagiellonian University Medical College, ul. Prądnicka, 31-202 Kraków, Poland, tel: +48 12 614 2381 , e-mail: jp38@interia.pl 
rehabilitation. Previous literature data indicate a beneficial effect of cardiac rehabilitation in ICD patients that included reduced anxiety and improved exercise capacity and QOL [5-7]. Unfortunately, previously reported studies included only small patients groups and evaluated effects of specific components of rehabilitation, such as physical training or psychological interventions. Results of the multicentre COPE-ICD study [8] evaluating effects of rehabilitation in ICD patients are expected. Another important issue is the safety of exercise training as a component of a rehabilitation program in ICD patients. Exercise in this group of patients requires a careful approach, individual workload planning, close supervision, and cooperation between the rehabilitation unit and the electrocardiologist who monitors ICD therapy [9]. Available literature lacks thorough analyses of the effects of early comprehensive cardiac rehabilitation after ICD implantation. Current knowledge base in this regard is thus incomplete, which prompted us to investigate this clinically important issue.

The aim of this study was to evaluate safety of early comprehensive cardiac rehabilitation after ICD implantation, and to assess its effect on exercise capacity, haemodynamic parameters, and QOL.

\section{METHODS}

We studied 45 consecutive patients, including 17 women and 28 men (mean age 62.2 years, range $24-81$ years) who were selected for a comprehensive cardiac rehabilitation program at 6 weeks after ICD implantation. A single-chamber ICD (VVI) was implanted in 16 patients, and a dual-chamber ICD (DDD) was implanted in 29 patients. Table 1 summarises indications for ICD implantation, concomitant diseases, and drugs used in the study group. Exclusion criteria included lack or withdrawal of consent for participation in the study, abnormal ICD

Table 1. Indications for ICD implantation, concomitant disease, and drug therapy in the study group

\begin{tabular}{|lc|}
\hline Primary SCD prevention & $39(86.7 \%)$ \\
Secondary SCD prevention & $6(13.3 \%)$ \\
Previous MI & $30(66.7 \%)$ \\
DCM & $15(33.3 \%)$ \\
Hypertension & $26(57.8 \%)$ \\
Diabetes type 2 & $24(53.3 \%)$ \\
Paroxysmal AF & $10(35.5 \%)$ \\
Amiodarone & $24(53.3 \%)$ \\
Sotalol & $10(22.2 \%)$ \\
Beta-blocker & $35(77.8 \%)$ \\
ACEl & $45(100 \%)$ \\
Statin & $30(66.7 \%)$ \\
\hline
\end{tabular}

ACEI - angiotensin-converting enzyme inhibitor; AF - atrial fibrillation; DCM - dilated cardiomyopathy; ICD — implanted cardioverter-defibrillator; MI — myocardial infarction; SCD — sudden cardiac death functioning, unclear antiarrhythmic drug therapy, anticipated ablation procedure, neoplasm, and contraindications to exercise according to the Polish Cardiac Society Section on Rehabilitation and Exercise guidelines [9]. Before inclusion to the study, all patients underwent ICD testing to evaluate device function and determine its appropriate programming mode. Comprehensive cardiac rehabilitation included a 2-week inpatient Phase I and a 12-week outpatient Phase II. During both phases, rehabilitation included supervised interval training, general fitness, agility, stretching and relaxation exercises, respiratory exercises, psychological evaluation, relaxation training, and patient education regarding lifestyle modification. We used 3 types of training: 1) interval endurance training (repeated sequences of short exercise and a resting period); 2) resistance training (1-2 sessions per week, each lasting 15-20 min); and 3) respiratory muscle exercises.

A prerequisite for endurance training was an exercise test used to determine target heart rate and workload during exercise. Training intensity and amount of exercise were determined individually for each patient taking into account his or her ICD programming (maximum heart rate during exercise $20 \mathrm{bpm}$ below the programmed threshold for VT intervention). Exercise intensity was set based on heart rate reserve and target heart rate during training according to the following formulas [9]:

1) heart rate reserve $=$ maximum heart rate during exercise - resting heart rate;

2) target heart rate during training $=$ resting heart rate $+40-80 \%$ of the heart rate reserve.

During Phase I, training was performed using models A, B, and $\mathrm{C}$ according to the current standards. Choice of the rehabilitation model was related to patient exercise capacity determined based on maximum load during the exercise test (Table 2) [9].

During Phase II, training was performed 5 times a week, and each training session included:

1. A 5- to 15-min warm-up including respiratory exercise, general fitness and coordination exercise, and light resistance exercise (rhythmical exercise engaging single muscle groups of alternating limbs to attenuate progressive muscle atrophy and weakness).

2. Aerobic interval endurance training lasting 10-30 min, including or alternating with resistance training.

3. A 5-min calm-down and relaxation period (stretching and respiratory exercise).

In all patients, the following evaluations and investigations were performed before and after rehabilitation program:

- History and physical examination including determination of the severity of heart failure as measured by the New York Heart Association (NYHA) class.

- 12-lead surface electrocardiogram (ECG).

- ICD interrogation and diagnostic data retrieval.

- Transthoracic echocardiography with measurements of the left ventricular end-systolic dimension (LVESD), left 
Table 2. Description of rehabilitation models A, B, and C (based on reference [9])

\begin{tabular}{|c|c|c|}
\hline $\begin{array}{l}\text { Rehabilitation model } \\
\text { Aerobic capacity }\end{array}$ & Rehabilitation program & Heart rate \\
\hline $\begin{array}{l}\text { A } \\
>5 \mathrm{MET} \\
>1.2 \mathrm{~W} / \mathrm{kg}\end{array}$ & $\begin{array}{l}\text { Respiratory exercises } 15-20 \text { min } 2 \times \text { day } \\
\text { Interval (endurance) training } 20-30 \text { min } \\
2 \text { min } 50 \mathrm{~W} \text { load } / 1-2 \text { min rest }\end{array}$ & $\begin{array}{l}\text { Heart rate during exercise: } 40-60 \% \text { of } \\
\text { heart rate during exercise test }\end{array}$ \\
\hline $\begin{array}{l}\text { B } \\
3-5 \mathrm{MET} \\
\text { Approx. } 1.2 \mathrm{~W} / \mathrm{kg}\end{array}$ & $\begin{array}{l}\text { Respiratory exercises } 15-20 \text { min } 2 \times \text { day } \\
\text { Ergometer interval (endurance) training: } 4 \text { min work, } 2 \text { min rest; } \\
1-2 \text { sessions per day/15 min, load approx. } 0-25 \mathrm{~W}\end{array}$ & $\begin{array}{l}\text { Increase in heart rate by } 30 \% \\
\text { compared to resting heart rate }\end{array}$ \\
\hline $\begin{array}{l}\mathrm{C} \\
<3 \mathrm{MET} \\
<0.5 \mathrm{~W} / \mathrm{kg}\end{array}$ & $\begin{array}{l}\text { Warm-up 5-10 min 1-2 × day } \\
\text { Respiratory exercises } 15-20 \text { min } 2 \times \text { day } \\
\text { Ergometer interval (endurance) training without load: } \\
4 \text { min work, } 3 \text { min rest; } 3 \text { sessions per week/20-30 min }\end{array}$ & $\begin{array}{l}\text { Increase in heart rate by } 10-15 \% \\
\text { compared to resting heart rate }\end{array}$ \\
\hline
\end{tabular}

MET — metabolic equivalent (oxygen uptake $3.5 \mathrm{~mL} / \mathrm{kg} / \mathrm{min}$ ); $\mathrm{W}$ - maximum load in Watts

ventricular end-diastolic dimension (LVEDD), left ventricular ejection fraction (LVEF) as determined using the Simpson method, and left atrial dimension.

- Spiroergometric exercise test performed on a treadmill using the modified Naughton protocol [10]. We evaluated duration of exercise (T spiroergo), heart rate at peak exercise (HR max), oxygen uptake at peak exercise (peak $\mathrm{VO}_{2}$ ) expressed in $\mathrm{mL} / \mathrm{kg}$ body mass per minute, peak carbon dioxide elimination $\left(\mathrm{VCO}_{2}\right.$ max) in $\mathrm{mL} / \mathrm{min}$, and respiratory exchange ratio (RER) or the ratio of carbon dioxide volume in the expired air to oxygen uptake $\left(\mathrm{RER}=\mathrm{VCO}_{2} / \mathrm{VO}_{2}\right)$. Anaerobic threshold was determined based on RER value of 1 .

- Evaluation of QOL using a Polish version of the SF-36 questionnaire [11]. We evaluated overall QOL (SF-total), physical functioning (SF-1), role limitation due to physical health (SF-2), complaints of pain (SF-3), overall wellbeing (SF-4), vitality (SF-5), social functioning (SF-6), role limitation due to emotional problems (SF-7), mental wellbeing (SF-8), QOL physical dimension based on SF-1, SF-2, SF-4 and SF-8, and QOL mental dimension based on SF-3, SF-5, SF-6 and SF-7. In the Polish version of the questionnaire used, higher scores indicate worse QOL, and lower scores indicate better QOL.

- Beck Depression Inventory (BDI) [12], with higher scores indicating more severe depressive symptoms.

\section{Statistical analysis}

Significance of changes in quantitative variables was evaluated using the one-sided Student $t$ test for paired samples or the Wilcoxon test. Correlations between changes in quantitative variables were evaluated using the Pearson ( $r$ ) or Spearman $\left(r_{s}\right)$ correlation coefficient. Significance of changes in categorical variables was evaluated using the $\chi^{2}$ test or the exact Fisher test. Analyses were performed using the STATISTICA package.

\section{RESULTS}

No deaths during the study and no complications or adverse events during rehabilitation or exercise testing were noted in our study group. Follow-up ICD interrogation revealed episodes of nonsustained VT without device intervention in 7 patients. In 1 (2.2\%) patient, an inappropriate ICD intervention occurred due to atrial fibrillation with rapid ventricular rate. In 2 (4.4\%) patients, appropriate ICD interventions occurred due to VF (2 VF episodes in 1 patient, and $1 \mathrm{VF}$ episode in another patient, all successfully defibrillated). In all cases, these interventions occurred at home during Phase II rehabilitation on days without training, 12-20 h after last training. We found a significant effect of rehabilitation on several evaluated parameters (Table 3). Of the haemodynamic parameters, an improvement in LVEF and a reduction in LVESD and LVEDD were noted. Rehabilitation was also associated with a significant improvement in exercise parameters including an increase in exercise duration and peak $\mathrm{VO}_{2}$. RER at peak exercise did not change significantly following rehabilitation, with only 2 patients in the study group reaching anaerobic threshold. BDI scores improved significantly after rehabilitation. We also found a significant improvement in overall $\mathrm{QOL}$, physical dimension of QOL, and the SF-2 score. The mental dimension of QOL worsened (Table 3). Exercise capacity as evaluated by the NYHA class improved significantly following rehabilitation (Fig. 1). Patient age and gender had no significant effect on the changes of the evaluated parameters following rehabilitation. We found negative correlation between peak $\mathrm{VO}_{2}$ change and changes in QOL parameters including overall QOL (Fig. 2) and the physical dimension of QOL (Fig. 3), amounting to an improvement in QOL with an increase in peak $\mathrm{VO}_{2}$. We also found a positive correlation between changes in BDI score and overall QOL (Fig. 4). Changes in haemodynamic parameters did not correlate with changes in the other evaluated parameters. 
Table 3. Effect of rehabilitation on study parameters

\begin{tabular}{|c|c|c|c|c|c|c|c|}
\hline Parameter & & $\bar{\chi}$ & Me & Min & Max & SD & $\mathbf{P}$ \\
\hline \multirow[t]{2}{*}{ LVEF [\%] } & Before & 30.09 & 28.00 & 8.000 & 75.00 & 12.75 & \multirow{2}{*}{0.002} \\
\hline & After & 35.43 & 33.00 & 15.000 & 74.00 & 13.40 & \\
\hline \multirow[t]{2}{*}{ LVESD [mm] } & Before & 49.88 & 50.50 & 23.00 & 91.00 & 13.03 & \multirow{2}{*}{0.040} \\
\hline & After & 48.25 & 47.00 & 23.00 & 86.00 & 13.09 & \\
\hline \multirow[t]{2}{*}{ LVEDD [mm] } & Before & 61.35 & 60.50 & 40.00 & 95.00 & 10.49 & \multirow{2}{*}{0.039} \\
\hline & After & 59.77 & 58.00 & 34.00 & 90.00 & 11.09 & \\
\hline \multirow[t]{2}{*}{ Left atrium [mm] } & Before & 45.18 & 45.00 & 23.00 & 93.00 & 11.58 & \multirow{2}{*}{0.290} \\
\hline & After & 44.75 & 45.00 & 28.00 & 64.00 & 8.09 & \\
\hline \multirow[t]{2}{*}{ T spiroergo [min] } & Before & 9.14 & 9.50 & 2.00 & 15.00 & 3.74 & \multirow{2}{*}{0.049} \\
\hline & After & 9.53 & 10.00 & 2.00 & 16.00 & 3.78 & \\
\hline \multirow[t]{2}{*}{ Peak $\mathrm{VO}_{2}[\mathrm{~mL} / \mathrm{kg} / \mathrm{min}]$} & Before & 21.3 & 20.5 & 8.8 & 45.9 & 9.2 & \multirow{2}{*}{0.007} \\
\hline & After & 24.2 & 22.1 & 8.8 & 47.3 & 10.3 & \\
\hline \multirow[t]{2}{*}{ RER } & Before & 0.91 & 0.91 & 0.60 & 1.16 & 0.13 & \multirow{2}{*}{0.299} \\
\hline & After & 0.90 & 0.90 & 0.60 & 1.16 & 0.13 & \\
\hline \multirow[t]{2}{*}{ HR max [bpm] } & Before & 112.21 & 108.00 & 76.00 & 178.00 & 23.65 & \multirow{2}{*}{0.432} \\
\hline & After & 113.49 & 115.00 & 67.00 & 161.00 & 20.81 & \\
\hline \multirow[t]{2}{*}{$\mathrm{VCO}_{2} \max$} & Before & 1107.0 & 1101.5 & 502.0 & 1969.0 & 388.3 & \multirow{2}{*}{0.370} \\
\hline & After & 1051.9 & 953.5 & 475.0 & 1956.0 & 377.3 & \\
\hline \multirow[t]{2}{*}{ BDI } & Before & 14.81 & 14.00 & 10.00 & 35.00 & 9.27 & \multirow{2}{*}{0.020} \\
\hline & After & 12.83 & 9.50 & 9.00 & 49.00 & 10.75 & \\
\hline
\end{tabular}

$\bar{\chi}$ — arithmetic mean; Me — median, Min — minimum, Max — maximum; SD — standard deviation; other abbreviations see text

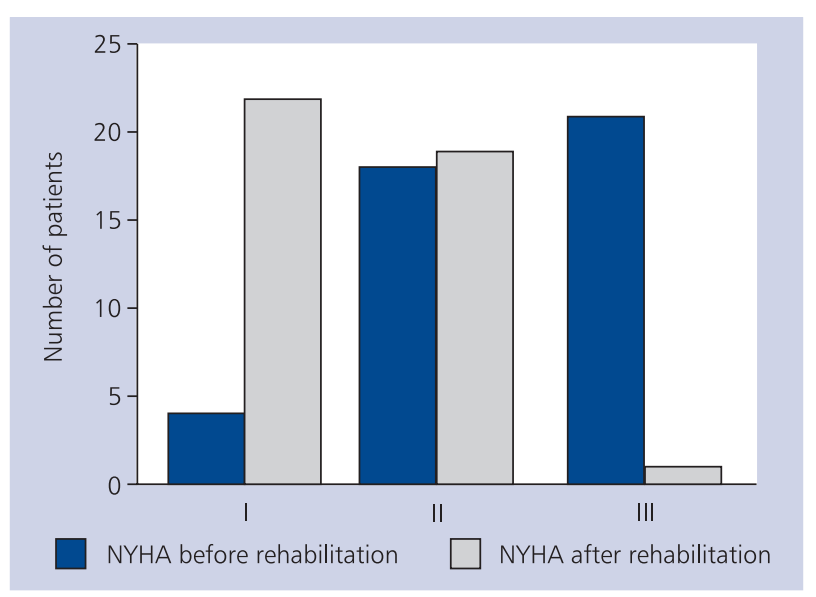

Figure 1. Severity of heart failure as measured by the New York Heart Association (NYHA) classification before and after rehabilitation. Before rehabilitation, 4 (8.9\%) patients were in NYHA class I, 19 (42.2\%) patients were in NYHA class II, and 22 (48.9\%) patients were in NYHA class III. After rehabilitation, 24 (53.3\%) patients were in NYHA class I, 20 (44.5\%) patients were in NYHA class II, and $1(2.2 \%)$ patient was in NYHA class III $(p<0.001)$

\section{DISCUSSION}

In the present study, we found a significant improvement in exercise capacity following a rehabilitation program, as mani-

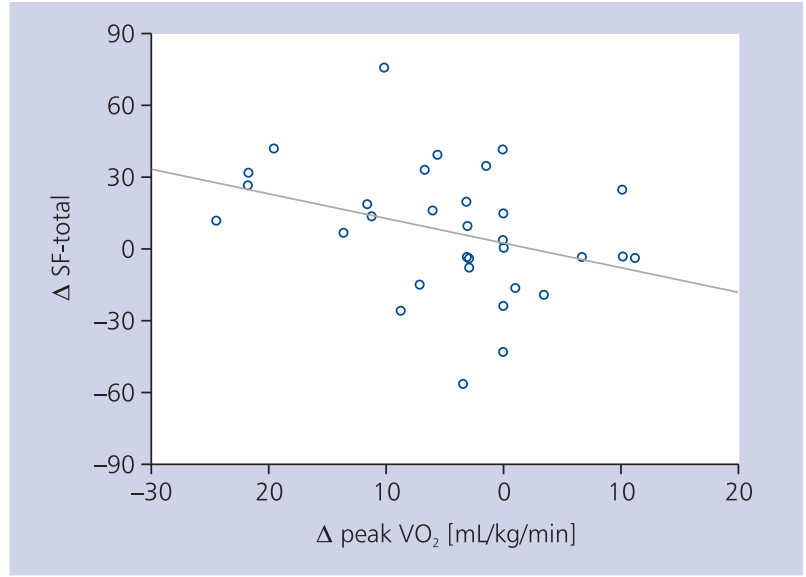

Figure 2. Correlation between the change in peak oxygen uptake $\left(\Delta\right.$ peak $\left.\mathrm{VO}_{2}\right)$ and the change in the overall quality of life $(\Delta$ SF-total $)$ after rehabilitation $(r=-0.339, p<0.05)$

fested by an increase in peak $\mathrm{VO}_{2}$ and longer exercise time. These results are consistent with few previous reports in the literature. Friedman et al. [13] reported an improvement in exercise capacity following rehabilitation in a group of patients that included 2 patients with ICD. The first clinical study of the effect of rehabilitation on exercise capacity in ICD patients 


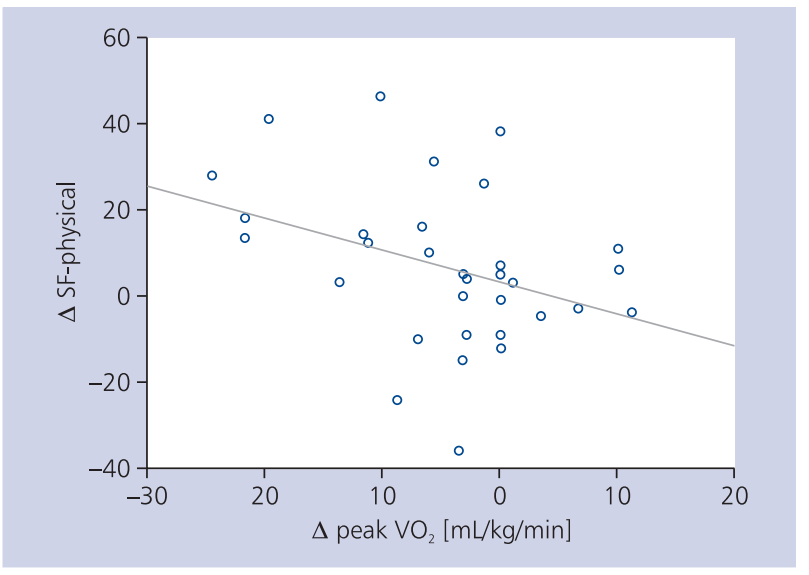

Figure 3. Correlation between the change in peak oxygen uptake $\left(\Delta\right.$ peak $\left.\mathrm{VO}_{2}\right)$ and the change in the physical index of quality of life ( $\Delta$ SF-physical) after rehabilitation $(r=-0.364$, $p<0.05)$

was published in 2001 [14]. In this study, an improvement in exercise capacity with rehabilitation was demonstrated in 8 ICD patients. Fitchet et al. [5] showed prolongation of exercise time following rehabilitation in 16 patients with ICD. Vanhees et al. [7] found a significant increase in peak $\mathrm{VO}_{2}$ and $\mathrm{HR}$ max after exercise training in 92 patients with ICD. Patients were referred for the training program both early and late after ICD implantation. Belardinelli et al. [15] found a beneficial effect of moderate intensity exercise training on exercise capacity, QOL, and endothelium-dependent vasodilatation in patients with ischaemic cardiomyopathy who had an ICD or a cardiac resynchronisation therapy-defibrillator (CRT-D) device implanted. These authors showed that the highest increases in peak $\mathrm{VO}_{2}$ and QOL occurred in CRT-D patients. During long-term follow-up (mean 24 months) after completion of the training program, no adverse events were found in the rehabilitated patients, while ventricular arrhythmia episodes that required hospital admission were noted in the control group which was not rehabilitated. We believe that our finding of improved exercise capacity was a beneficial effect of the rehabilitation program that we administered. It also seems that the improvement in exercise capacity following rehabilitation in ICD patients results from additional beneficial effects that are specific for this patient group. Patients with ICD usually limit their physical activity due to fears for arrhythmia occurrence and device intervention. Participation in the exercise training clearly contributes to lowering fear of physical activity in ICD patients, allowing them to increase their daily life physical activity [16]. In our study group, we found a significant improvement in haemodynamic parameters evaluated by echocardiography, including an increase in LVEF and decreases in LVEDD and LVESD following rehabilitation. Available literature lack studies on the effect of rehabilitation in ICD patients on their left ventricular

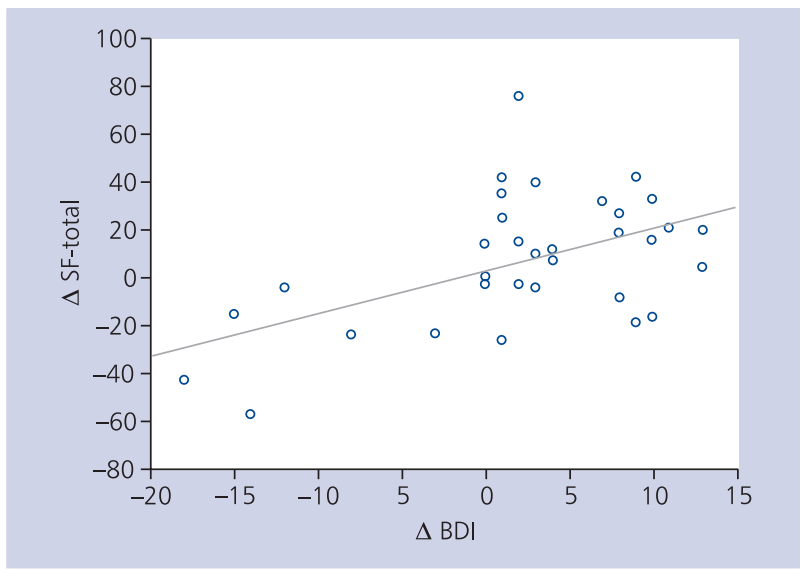

Figure 4. Correlation between the change in the overall quality of life ( $\Delta$ SF-total) and the change in the Beck Depression Inventory $(\Delta \mathrm{BDI})(\mathrm{r}=0.521, \mathrm{p}=0.002)$

systolic function. It seems that the observed improvement might have resulted from established beneficial effects of rehabilitation reported in patients with heart failure, including reduced progression of the underlying disease and beneficial effects on the endothelium and myocardial perfusion [17]. Changes in peripheral vasculature and skeletal muscle with reduction in the afterload as a result of training also play a significant role [18]. A similar explanation may be offered for the observed significant improvement in heart failure severity as assessed by the NYHA class. In our study, we did not find a correlation between improvement in LVEF and changes in exercise capacity parameters. This is consistent with the current understanding the left ventricular systolic function as assessed by resting echocardiography does not correlate with exercise capacity [19]. A very important aspect of comprehensive cardiac rehabilitation in ICD patients is the safety of exercise training. These patients are a high-risk group due to a possibility of life-threatening ventricular arrhythmia and usually significant reduced left ventricular systolic function. For these reasons, clinicians were previously reluctant to refer these patients for cardiac rehabilitation. ICD deactivation for the duration of exercise test and training sessions was advised to avoid inappropriate device activation [20]. Ventricular arrhythmia leading to device intervention may occur during exercise in ICD patients. In addition, an increase in heart rate during exercise may result in an inappropriate device intervention. For these reasons, guidelines recommend that rehabilitation in this patient group be undertaken according to an individually determined exercise schedule that takes into account ICD programming parameters, particularly in regard to VT detection. Close physician supervision during exercise is required, with easily available cardiopulmonary resuscitation equipment. The rehabilitation unit should also be equipped with a magnet allowing ICD deactivation in case of inappro- 
priate device interventions [9]. In our study group, cardiac rehabilitation program was undertaken in accordance to the current standards, and no adverse events or ICD intervention during rehabilitation or exercise testing were noted in any of the patients. Appropriate device interventions observed in 2 of our patients were not related to exercise. These observations are supported by the literature data. Kamke et al. [21] found that rehabilitation in ICD patients is not related to a risk of significant complications. Davids et al. [16] demonstrated less ICD intervention, both related and unrelated to exercise, in patients undergoing outpatient cardiac rehabilitation compared to the non-rehabilitated group. In a group of 16 ICD patients reported by Fitchet et al. [5], no ICD interventions were noted during exercise testing, supervised rehabilitation, or home-based exercising. In this patient group, 3 appropriate ICD interventions for VT were noted that were unrelated to exercise. In a group of ICD patients participating in exercise training who were reported by Vanhees et al. [7], 4 patients did not complete the rehabilitation program, including 3 due to device activation for $\mathrm{VT}$ during exercise, and 1 patient due to multiple device interventions that occurred several days after a training session. Among the remaining 92 patients reported by these authors, haemodynamically stable VT occurred during an exercise test in 1 patient and was terminated by the ICD with overdrive pacing. In another patient in this group, an asymptomatic VT episode with the rate of $170 \mathrm{bpm}$ occurred during a training session and was also terminated by overdrive pacing administered by the ICD. Inappropriate ICD activation occurred during training in 1 patient, and appropriate ICD interventions for VT were noted between training sessions in 6 patients. In summary, our findings support the available literature data indicating the safety of comprehensive cardiac rehabilitation in ICD patients.

In our study, QOL was evaluated using the SF-36 (Short Form Health Survey) questionnaire which is considered reliable and reproducible [22]. In the previous studies, this questionnaire was also used to evaluate QOL in ICD patients [2]. In our study, we found a significant correlation between an increase in exercise capacity (peak $\mathrm{VO}_{2}$ ) and an improvement of overall QOL and its physical dimension. Thus, we believe that the improvement in exercise capacity following training had an important effect on the observed improvement in QOL parameters. Previous literature lacks prospective studies to evaluate the effect of early comprehensive cardiac rehabilitation following ICD implantation on QOL as assessed using the SF-36 questionnaire. In contrast, Carroll et al. [2] found worsening of the physical QOL dimension during 4 years of follow-up in a group of 81 patients after ICD implantation who did not participate in a cardiac rehabilitation program. In our study group, the mental QOL dimension worsened, which was likely related to an adverse effect of ICD implantation on this aspect of QOL [2]. During a relatively short duration of follow-up after ICD implanta- tion, participation in a rehabilitation program was not able to prevent this effect. It cannot be excluded that the mental QOL dimension would improve during a longer follow-up. This hypothesis is supported by data from other studies. Carroll et al. [2] found an improvement in the mental QOL dimension during a 4-year follow-up after ICD implantation. Irvine et al. [6] found a beneficial effect of a behavioural therapy program on the mental QOL dimension after ICD implantation. It seems that our patients might benefit from extending the rehabilitation program with additional elements of psychological care, similarly to a view presented by Pedersen et al. [23]. An important problem in patients with an implanted ICD are depressive symptoms. Suzuki et al. [4] used the Zung Self-Rating Depression (SDS) scale and found depression to occur in 32\% of patients before ICD implantation. At 2 years, depression was found in $28 \%$ of these patients. Thomas et al. [24] used BDI and found a decrease in depressive symptoms at 2 years after ICD implantation. Whang et al. [25] analysed the Triggers of Ventricular Arrhythmias (TOVA) study data and found an increase in the rate of ICD interventions for VT or VF among patients with depression as measured using the Centre for Epidemiological Studies-Depression (CES-D) scale. In our study, we found an improvement in the severity of depressive symptoms following a comprehensive cardiac rehabilitation program. In the literature, there are no data on the effect of early comprehensive cardiac rehabilitation after ICD implantation on the rates of depression as measured using BDI. In our study, a decrease in the severity of depressive symptoms correlated with an improvement in QOL parameters. This is consistent with observations by Dudek et al. [26] in coronary artery disease patients after percutaneous coronary interventions. These authors believed that mood disturbances play an important role in subjective evaluation of QOL. An improvement in the SF-36 questionnaire may thus result in part from reduced depressive symptoms.

\section{Limitations of the study}

Clear limitations of the present study were small patient sample, short duration of follow-up, and a lack of control group that would not undergo rehabilitation. In addition, we did not analyse the effect of rehabilitation on patient survival and the risk of cardiovascular events. We cannot exclude an effect of drug therapy and ICD implantation itself on our results indicating significant benefits of early comprehensive cardiac rehabilitation in patients after ICD implantation. Our findings advance previous knowledge on this topic, which was based on relatively few literature data, and are also of potential practical value. They should encourage referral of ICD patients for comprehensive cardiac rehabilitation programs.

\section{CONCLUSIONS}

An improvement in left ventricular systolic function, exercise capacity and QOL (SF-total and physical index) and a reduc- 
tion of depressive symptoms were observed in patients who took part in a program of early comprehensive cardiac rehabilitation after ICD implantation. No complications or side effects during rehabilitation sessions or exercise tests were observed in any of patients in the study group.

\section{Conflict of interest: none declared}

\section{References}

1. Zipes DP, Camm AJ, Borggrefe M et al. ACC/AHA/ESC gudelines for management of patients with ventricular arrhythmias and the prevention of sudden cardiac death. A report of the American College of Cardiology/American Heart Association Task Force and the European Society of Cardiology Committee for Practice Guidelines (Writing Committee to Develop Guidelines for Management of Patients with Ventricular Arrhythmias and the Prevention of Sudden Cardiac Death) developed in collaboration with The European Heart Rhythm Association and the Heart Rhythm Society. Europace, 2006; 8: 746-837.

2. Caroll DL, Hamilton GA. Long-term effects of implanted cardioverter-defibrillators on health status, quality of life and psychological state. Am J Crit Care, 2008; 17: 222-230.

3. Kamphuis HCM, de Leeuw JRJ, Derksen R et al. Implantable cardioverter defibrillator receipients: Quality of life in recipients with and without ICD shock delivery. Europace, 2003; 5: 381-389.

4. Suzuki T, Tsuyoshi S, Kuwahara K et al. Prevalence and persistence of depression in patients with implantable cardioverter defibrillator : a 2-year longitudinal study. Pacing Clin Electrophysiol, 2010; 33: 1445-1461.

5. Fitchet A, Doherty PJ, Bundy C et al. Comprehensive cardiac rehabilitation programme for implantable cardioverter-defibrillator patients: a randomized controlled trial. Heart, 2003; 89: 155-160.

6. Irvine J, Firestone J, Ong L et al. A randomized controlled trial of cognitive behavior therapy tailored to psychological adaptation to an implantable cardioverter defibrillator. Psychosom Med, 2011; 73: 226-233.

7. Vanhees L, Kornaat M, Defoor J et al. Effects of exercise training in patients with an implantable cardioverter defibrillator. Eur Heart J, 2004; 25: 1120-1126

8. Berg SK, Svendsen JH, Zwisler AD et al. COPE-ICD: a randomized clinical trial studying the effects and meaning of a comprehensive rehabilitation programme for ICD recipients-design, intervention and population. BMC Cardiovasc Disord, 2011; 11: 33-39.

9. Piotrowicz R, Dylewicz P, Jegier A et al. Kompleksowa rehabilitacja kardiologiczna. Stanowisko komisji ds. opracowania standardów rehabilitacji kardiologicznej Polskiego Towarzystwa Kardiologicznego. Folia Cardiol, 2004; 11 (suppl. A): A1-A48.

10. Fletcher GF, Balady GJ, Amsterdam EA et al. Exercise standards for testing and training. A statement for healthcare professionals from the American Heart Association. Circulation, 2001;104: 1694-1740.

11. Tylka J, Piotrowicz R. Kwestionariusz oceny jakości życia SF-36: wersja polska. Kardiol Pol, 2009; 67: 1166-1169.
12. Beck AT, Steer RA, Garbin GM. Psychometric properties of the Beck Depression Inventory: Twenty-five years of evaluation. Clinical Psychology Rev, 1988; 8: 77-100.

13. Friedman AW, Lipman RC, Silver SJ et al. Cardiac rehabilitation/exercise in patients with implantable cardioverter defibrillators. J Natl Med Assoc, 1996; 88: 374-378.

14. Vanhees L, Kornaat M, Defoor J et al. Exercise performance and training in patients with implantable cardioverter-defibrillators and coronary heart disease. Am J Cardiol, 2001; 87: 712-715.

15. Belardinelli R, Capestro F, Misiani A et al. Moderate exercise training improves functional capacity, quality of life and endothelium-dependent vasodilation in chronic heart failure patients with implantable cardioverter defibrillators and cardiac resynchronization therapy. Eur J Cardiovasc Prev Rehabil, 2006; 13: 818-825.

16. Davids JS, McPherson CA, Earley C at al. Benefits of cardiac rehabilitation in patients with implantable cardiovrter-defibrillators: a patients survey. Arch Phys Med Rehabil, 2005; 86: 1924-1928.

17. Smart N, Marwick TH. Exercise training for patients with heart failure: a systematic review of factors that improve mortality and morbidity. Am J Med, 2004; 116: 693-706.

18. Clark AL, Poole-Wilson PA, Coats AJS. Exercise limitation in chronic heart failure : central role of the periphery. J Am Coll Cardiol, 1996; 28: 1092-1102.

19. Francisa JA, Park M, Levine TB. Lack of corelation between exercise capacity and indexes of resting left ventricular performance in heart failure. Am J Cardiol, 1981; 47: 33-39.

20. Lampman RM, Knight BP. Prescribing exercise training for patients with defibrillators. Am J Phys Med Rehabil, 2000; 79: 292-297.

21. Kamke W, Dovifat C, Schranz M et al. Cardiac rehabilitation in patients with implantable defibrillators. Feasibility and complications. Z Kardiol, 2003; 92: 869-875.

22. Ware JE, Sherbourne CD. The MOS 36-item short- form health survey (SF-36). Conceptual framework and item selection. Med Care, 1992; 30: 473-483.

23. Pedersen SS, van den Broek KC, Sears SF. Psychological intervention following implantation of an implantable defibrillator: a review and future recommendations. Pacing Clin Electrophysiol, 2007; 30: 1546-1554.

24. Thomas SA, Friedmann E, Gottlieb SS et al.; on behalf of the Sudden Cardiac Death in Heart Failure Trial Investigators. Changes in psychosocial distress in outpatients with heart failure with implantable cardioverter defibrillators. Heart Lung, 2009; 38: 109-120.

25. Whang W, Kubzansky LD, Kawachi I et al. Depression and risk of sudden cardiac death and coronary heart disease in women: results from theNurses' Health Study. J Am Coll Cardiol, 2009; 53: 950-958.

26. Dudek D, Datka W, Siwek M et al. Jakość życia a objawy depresyjne u pacjentów z chorobą niedokrwienną serca po zabiegach przezskórnej angioplastyki wieńcowej w ciągu rocznej obserwacji. Psychiatr Pol, 2007; 41: 229-242. 


\title{
Skuteczność i bezpieczeństwo wczesnej kompleksowej rehabilitacji kardiologicznej po wszczepieniu kardiowertera-defibrylatora
}

\author{
Jacek Śmiałek ${ }^{1}$, Jacek Lelakowski², Jacek Majewski ${ }^{2}$ \\ ${ }^{1}$ Klinika Rehabilitacji, Szpital im. Jana Pawła II, Kraków \\ ${ }^{2}$ Klinika Elektrokardiologii, Uniwersytet Jagielloński, Collegium Medicum, Szpital im. Jana Pawła II, Kraków
}

\section{Streszczenie}

Wstęp: Aktualnie podstawową metodą o udokumentowanej skuteczności w zapobieganiu nagłej śmierci sercowej (SCD) jest implantacja kardiowertera-defibrylatora (ICD). Wykazano, że u osób z ICD dochodzi do obniżenia jakości życia (QOL). U wielu pacjentów po implantacji urządzenia rozwijają się objawy depresyjne. Chorzy z ICD stanowią zatem grupę, która może odnieść bardzo istotne korzyści z udziału w programie kompleksowej rehabilitacji kardiologicznej.

Cel: Celem pracy były ocena bezpieczeństwa i analiza korzyści wczesnej kompleksowej rehabilitacji kardiologicznej po implantacji ICD.

Metody: Badana grupa liczyła 45 osób, 17 kobiet i 28 mężczyzn w wieku śr. 62,2 roku (24-81 lat) zakwalifikowanych do kompleksowej rehabilitacji kardiologicznej po upływie 6 tygodni od implantacji ICD. U 16 pacjentów implantowano ICD jednojamowy (VVI), a u 29 osób dwujamowy (DDD). U 39 (86,7\%) chorych ICD wszczepiono w ramach profilaktyki pierwotnej, a u pozostałych $6(13,3 \%)$ w ramach profilaktyki wtórnej SCD. Kryteria wykluczenia z badań obejmowały: brak lub wycofanie zgody na udział w badaniu, zaburzenia funkcjonowania ICD, nieustaloną farmakoterapię arytmii, planowany zabieg ablacji, chorobę nowotworową i przeciwwskazania do ćwiczeń wg standardów Sekcji Rehabilitacji i Wysiłku Fizycznego PTK. Program rehabilitacji obejmował dwa etapy: I - 2-tygodniową rehabilitację stacjonarną, II - 12-tygodniową rehabilitację ambulatoryjną. W skład programu rehabilitacji wchodziły: monitorowany trening interwałowy, ćwiczenia ogólnousprawniające, psychoterapia i treningi relaksacyjne, a także edukacja w zakresie modyfikacji stylu życia. Intensywność treningu i wielkość obciążeń treningowych dobierano indywidualnie z uwzględnieniem programu ICD (górną granicę maksymalnego tętna wysitkowego dla danego pacjenta ustalano na poziomie 20/min poniżej zaprogramowanego progu interwencji ICD dla częstoskurczu komorowego). Przed rozpoczęciem rehabilitacji i po jej zakończeniu wykonywano przezklatkowe badanie echokardiograficzne z oceną frakcji wyrzutowej lewej komory (LVEF) metodą Simpsona, objętości końcoworozkurczowej lewej komory (LVEDD), objętości końcowoskurczowej lewej komory (LVESD). W celu oceny wydolności wysiłkowej wykonywano test spiroergometryczny na bieżni wg zmodyfikowanego protokołu Naughtona z oceną czasu trwania wysiłku (T spiroergo), częstotliwości rytmu serca na szczycie wysiłku (HR max), szczytowego zużycia tlenu (peak VO ${ }_{2}$ ), maksymalnej eliminacji dwutlenku węgla i współczynnika wymiany oddechowej (RER). Ponadto stosowano polską wersję kwestionariusza SF-36 do oceny QOL oraz inwentarz depresji Becka (BDI).

Wyniki: U żadnego z pacjentów nie wystąpiły powikłania lub objawy niepożądane w trakcie treningu lub testów wysiłkowych. Po rehabilitacji stwierdzono: wzrost LVEF $(30,09 \pm 12,75$ vs. 35,43 $\pm 13,4 \% ; p=0,002)$, spadek LVEDD $(61,3 \pm 10,5$ vs. 59,8 $\pm 11,1$ mm; $p=0,04)$, spadek LVESD $(49,9 \pm 13$ vs. $48,3 \pm 13 ; p=0,04)$. W zakresie parametrów wydolności wysiłkowej wykazano wzrost peak $\mathrm{VO}_{2}(21,3 \pm 9,2$ vs. $24,2 \pm 10,3 \mathrm{ml} / \mathrm{kg} / \mathrm{min} ; \mathrm{p}=0,007)$ oraz wydłużenie T spiroergo $(9,14 \pm 3,7$ vs. 9,53 $\pm 3,8 \mathrm{~min} ; \mathrm{p}<0,05)$. Objawy depresyjne uległy zmniejszeniu, rejestrowano spadek BDI $(14,81 \pm 9,27$ vs. $12,83 \pm 10,75 ; p=0,02)$. Stwierdzono znamienną poprawę w zakresie całkowitego wskaźnika QOL ( $p<0,05)$, wymiaru fizycznego QOL ( $p=0,02)$ oraz wskaźnika SF-2 ( $p=0,02)$. Zaobserwowano pogorszenie wymiaru mentalnego QOL. Wykazano poprawę w zakresie objawów niewydolności serca wg klasyfikacji NYHA ( $p<0,001)$. Zmiana peak $\mathrm{VO}_{2}$ korelowała istotnie ze zmianami QOL w zakresie całkowitego wskaźnika QOL $(r=-0,34)$ i wymiaru fizycznego QOL $(r=-0,36)$. Oznacza to, że wzrostowi peak $\mathrm{VO}_{2}$ odpowiadała poprawa QOL. Stwierdzono istotną korelację między zmianą oceny depresji wg BDI a zmianą całkowitego wskaźnika QOL ( $r=0,52)$.

Wnioski: U pacjentów poddanych wczesnej kompleksowej rehabilitacji kardiologicznej po implantacji ICD zaobserwowano poprawę wydolności układu sercowo-naczyniowego, czynności skurczowej lewej komory, wydolności wysiłkowej, jakości życia w zakresie indeksu całkowitego i wymiaru fizycznego (wg kwestionariusza SF-36) oraz zmniejszenie nasilenia depresji. W badanej grupie u żadnego z pacjentów nie wystąpiły powikłania lub objawy niepożądane w trakcie zajęć rehabilitacyjnych lub testów wysiłkowych.

Słowa kluczowe: implantowany kardiowerter-difibrylator (ICD), rehabilitacja

Kardiol Pol 2013; 71, 10: 1021-1028 